Enlighten: Jurnal Bimbingan Konseling Islam Volume 1 No 2 (Juli-Desember 2018) Hlm:150-164 Tersedia online di http://journal.iainlangsa.ac.id/index.php/enlighten P-ISSN 2622-8912, E-ISSN 2622-8920

\title{
THE RELATIONSHIP BETWEEN SELF-EFFICACY AND LECTURER'S ASSERTIVE BEHAVIOR WITH FOREIGN LANGUAGE ANXIETY
}

\author{
Dedy Surya $^{1}$, Asih Menanti ${ }^{2}$, Nina Siti Salmaniah Siregar ${ }^{3}$
}

${ }^{1}$ Program Studi Bimbingan dan Konseling Islam Institut Agama Islam Negeri Langsa

2 Program Studi Bimbingan dan Konseling Universitas Negeri Medan

${ }^{3}$ Program Studi Magister Psikologi Universitas Medan Area

Email: ${ }^{1}$ dedysurya@iainlangsa.ac.id; ${ }^{2}$ asihmenanti@yahoo.com

${ }^{3}$ ninasalmaniah@yahoo.com

\begin{abstract}
This quantitative research aimed to determine the relationship between self-efficacy and lecturer's assertive behavior with foreign language anxiety experienced by university student. The population in this study was the students of the Department of English Education, State Institute for Islamic Studies Langsa. The samples were selected by using Stratified Random Sampling technique and sorted 147 students in semester 2, 4, and 6 that spread proportionally. The data were collected by using Foreign Language Classroom Anxiety Scale (FLCAS), self-efficacy scale, and lecturer's assertive behavior scale. The data, then, were analyzed by multivariate linear regression. The result showed that self-efficacy and lecturer's assertive behavior significantly contributed to foreign language anxiety. The effective contribution of self-efficacy and lecturer's assertive behavior to foreign language anxiety was $58,4 \%$.
\end{abstract}

Keyword: foreign language anxiety, self-efficacy, lecturer's assertive behavior

Di era perkembangan teknologi dan informasi, kemampuan berbahasa memainkan peranan yang amat penting. Kini seseorang dituntut untuk menguasai lebih dari satu bahasa selain dari bahasa ibunya (native language). Kemampuan berbahasa asing menjadi sangat substansial, mengingat bahwa bahasa merupakan alat yang paling efektif digunakan untuk berkomunikasi. Dengan kemampuan 
DOI : 10.32505/enlighten.v1i2.784

berbahasa asing yang baik, seseorang mampu mengakses informasi tanpa batas serta berinteraksi secara global dengan masyarakat luas di dunia.

Dewasa ini, Bahasa Inggris tidak hanya digunakan terbatas sebagai bahasa pengantar (lingua franca) antarpenutur bahasa berbagai negara di seluruh dunia, namun fungsinya meluas berbagai bahasa ilmu pengetahuan, teknologi infomasi, sosial, ekonomi, bahkan bidang seni juga turut disajikan dengan menggunakan Bahasa Inggris. Hal-hal tersebut yang menyebabkan Bahasa Inggris disebut dengan bahasa global (Crystal, 2003).

Pesatnya perkembangan dunia komunikasi dan interaksi global telah menempatkan Bahasa Inggris sebagai media yang mutlak dibutuhkan. Seorang sarjana yang tidak memiliki kemampuan Bahasa Inggris yang memadai akan banyak mengalami kesulitan dalam dunia kariernya atau saat melanjutkan studinya. Menyadari akan urgensinya tersebut, beberapa negara di dunia telah menjadikan Bahasa Inggris sebagai salah satu muatan wajib dalam kurikulum pendidikannya, temasuk Indonesia.

Hingga saat ini, berbagai studi telah dilakukan untuk menemukan cara yang tepat untuk memaksimalkan proses belajar yang mencakup upaya-upaya untuk menemukan metode dan teknik pengajaran yang paling efektif dalam membantu siswa untuk mengakuisisi bahasa. Di samping itu juga telah banyak dilakukan penelitian untuk menemukan lingkungan dan keadaan belajar yang paling ideal untuk mempelajari bahasa.

Krashen (1982), dari berbagai riset yang telah dilakukan, menyebutkan ada tiga kategori variabel afektif yang berkaitan erat dengan kesuksesan seseorang dalam mengakuisisi bahasa, yaitu: motivasi, kepercayaan diri, dan kecemasan. Dulay, Burt, dan Krashen (1982) menyebut aspek psikologis yang menghalangi proses mempelajari suatu bahasa dengan istilah affective filter. Lebih lanjut Stevick (1976; dalam Krashen, 1982) menjelaskan bahwa seseorang yang memiliki sikap yang tidak optimal dalam mempelajari bahasa akan cenderung memiliki affective filter yang lebih tinggi dan menyebabkan masukan (input) yang rendah dalam mengakusisi bahasa. Sebaliknya, sikap yang kondusif akan menurunkan affective filter yang berimplikasi pada peningkatan input dalam mempelajari bahasa. Dengan 
DOI : 10.32505/enlighten.v1i2.784

kata lain bahwa perasaan yang kondusif dari seorang pelajar bahasa berpengaruh besar terhadap efektivitas dan efisiensi dalam mempelajari bahasa.

Meskipun tuntutan penguasaan Bahasa Inggris cukup tinggi, kecemasan dalam berbahasa Inggris sebagai bahasa asing masih sering ditemukan pada mahasiswa Jurusan Pendidikan Bahasa Inggris. Mereka masih enggan berbahasa Inggris dengan orang lain dan tidak jarang juga ditemukan mahasiswa yang masih berkesulitan untuk berbahasa Inggris secara lisan saat menyajikan hasil diskusinya. Tentu hal ini menjadi menarik dengan asumsi bahwa mahasiswa yang memilih jurusan tersebut tentunya adalah orang-orang yang telah memiliki kemampuan dasar Bahasa Inggris yang baik dan dipersiapkan untuk menjadi guru dalam mata pelajaran Bahasa Inggris.

Kecemasan yang timbul saat berkomunikasi dengan menggunakan bahasa asing diistilah kan dengan foreign language anxiety. Kecemasan ini adalah kecemasan khusus yang ditimbulkan akibat dari respon terhadap pembelajaran bahasa target dan penggunaannya (Horwitz, dkk., dalam Horwitz, 2016). Gardner dan MacIntyre (1994, dalam Humphries, 2011) menjelaskan bahwa kecemasan berbahasa adalah perasaan tegang dan takut secara khusus terkait dengan konteks bahasa kedua, termasuk dalam hal berbicara, mendengarkan, dan pembelajaran. Kecemasan merupakan reaksi emosional yang umum terjadi pada kelas bahasa asing (Luo, 2014). Peneliti-peneliti telah menemukan bahwa sepertiga dari pelajar bahasa asing mengalami kecemasan, minimal pada level moderat (Horwitz, 2001).

Tóth (2010) menggolongkan faktor-faktor yang berkontribusi terhadap kecemasan yang dialami ke dalam beberapa kelompok yaitu: 1) the nature of foreign language communication (faktor yang berhubungan dengan kecemasan yang melekat dalam komunikasi dengan bahasa target dibandingkan ketika menggunakan bahasa ibu yang menjadi bahasa asli seseorang, 2) personality and character (faktor kepribadian dan karakter dari pelajar bahasa,

3) being foreign language major (kecemasan dapat timbul karena pemilihan jurusan bahasa asing), 4) classroom situation, teachers, and peers (faktor yang berhubungan dengan kondisi belajar, guru dan lawan bicara), 5) target language competence (hal yang berhubungan dengan kompetensi bahasa target yang dimiliki oleh seorang peserta didik, 6) instructional practice (faktor yang berhubungan dengan tujuan 
DOI : 10.32505/enlighten.v1i2.784

pembelajaran bahasa di dalam kelas), dan 7) lack of authentic communication (faktor keterbatasan akan kesempatan dan ruang para peserta didik untuk mengalami proses komunikasi yang sesungguhnya).

Salah satu faktor kepribadian dan karakter yang sangat mempengaruhi kecemasan adalah efikasi diri. Dikaitkan dengan dunia akademik, efikasi diri dimaknai sebagai penilaian pribadi terhadap kemampuan diri untuk mengatur dan melaksanakan tugas untuk memperoleh prestasi (Zimmerman, 2009). Ottens (1991, dalam Yoenanto dan Rahadianto, 2014) menjelaskan bahwa peserta didik yang menerima keyakinan yang salah mengenai cara menetapkan nilai dalam diri, cara memotivasi diri, dan cara mengatasi kecemasan adalah berpikir yang salah yang menyebabkan kecemasan tersebut muncul. Dengan demikian, efikasi diri dibutuhkan oleh pelajar agar kecemasan tersebut tidak timbul.

Heider (1958) menyebutkan bahwa kemampuan seseorang, termasuk pula kemampuan berbicara, tidak hanya menyangkut permasalahan yang berhubungan dengan fisik dan keterampilan yang dimilikinya saja, namun juga ditentukan oleh faktor-faktor psikologis seperti kepercayaan diri. Rakhmat (2005) menyatakan apabila seseorang merasa rendah diri, ia akan cenderung mengalami kesulitan dalam mengomunikasikan ide pikiran pada orang yang dihormatinya dan merasa takut untuk mengartikulasikannya di depan khalayak ramai karena takut orang yang lain akan menyalahkannya.

Selain efikasi diri, Horwitz, dkk. (1986) menyatakan bahwa foreign language anxiety yang dialami oleh peserta didik juga bersumber dari pengajar. Kecemasan berbahasa asing yang dialami pembelajar bahasa disebabkan oleh faktor perilaku seorang pengajar. Pemilihan serta penentuan metode dan teknik mengajar yang membuat peserta didik merasa tidak siap akan berimplikasi pada timbulnya kecemasan. Perilaku guru yang menimbulkan rasa tertekan akan meningkatkan rasa cemas. Seorang pendidik yang bersahabat dan menghargai hakhak pelajarnya akan menghilangkan ketakutan saat melakukan kesalahan di dalam kelas.

Dalam kajian psikologi, perilaku yang lugas namun tetap mampu menghargai hak-hak orang lain sebagai lawan bicaranya disebut dengan perilaku asertif (assertive behavior). Townend (2007) mendefinisikan asertivitas sebagai 
DOI : 10.32505/enlighten.v1i2.784

kemampuan seseorang untuk menyampaikan pikiran dan perasaannya dengan cara yang tepat dan tanpa ragu serta menghargai akan karakter individu lain. Perilaku agresif menempatkan hak pribadi untuk mengekspresikan diri sejajar dengan hal orang lain untuk dihormati. Seseorang pengajar yang asertif dalam memberikan respon dari seorang pendidik dengan bijak dan tepat. Ketika ia menemukan sesuatu hal yang salah atau menurutnya kurang berkenan, ia akan mampu berperilaku secara wajar serta mengekspresikan emosi dan idenya dengan tepat dengan tidak mengabaikan hak-hak peserta didik. Perilaku seperti ini akan dapat meminimalisasi rasa cemas yang dialami oleh para peserta didik, terutama kecemasan akan dinilai negatif ketika melakukan kesalahan dalam proses belajar.

Berdasarkan hasil pengamatan dan wawancara dengan beberapa dosen diperoleh data bahwa banyak mahasiswa pada jurusan ini yang merasa takut untuk berbahasa Inggris saat berinteraksi dengan rekannya, baik di dalam maupun di luar kelas. Bahkan tidak jarang juga ditemukan mahasiswa yang kesulitan untuk berbahasa Inggris, baik saat mempresentasikan hasil tugasnya maupun saat mempraktikkan cara mengajar. Kenyataan ini tidak hanya ditemukan pada mahasiswa pada tingkat bawah saja, namun juga terjadi pada mahasiswa yang duduk pada tingkat akhir. Kondisi ini menunjukkan rendahnya keyakinan diri akan kemampuan yang mereka miliki yang kemudian berimplikasi kepada meningkatnya kecemasan ketika mereka ingin berkomunkasi dalam Bahasa Inggris. Lebih lanjut, kecemasan menjadi semakin meningkat disebabkan perilaku dosen dalam mengajar dan memberikan umpan balik dalam pembelajaran membuat mereka menjadi berani atau takut dalam berbahasa Inggris. Kemungkinan yang terjadi adalah apabila mereka menganggap perilaku dosen dalam mengajar membuat mereka nyaman, kecemasan mereka cenderung akan tereduksi. Sebaliknya, ketika mereka menganggap bahwa perilaku dosen cenderung agresif, maka kecemasan yang timbul akan meningkat.

Dari paparan di atas, dapat disimpulkan bahwa kecemasan berbahasa asing yang timbul pada diri mahasiswa tidak terlepas dari perilaku dosen dalam mengajar atau berinteraksi dengan mahasiswanya. Perilaku dosen yang asertif mendorong rasa kepercayaan diri mahasiswa untuk mengungkapkan pengetahuan, ide, pikiran, dan perasaannya melalui kemampuan berbahasa asing. Dengan demikian, secara 
DOI : 10.32505/enlighten.v1i2.784

tidak langsung, perilaku dosen yang asertif mampu menumbuhkan efikasi diri mahasiswa sebagai pembelajar bahasa asing.

Keyakinan akan kemampuan diri merupakan kunci utama dalam menyelesaikan aktivitas atau tugas-tugas yang diberikan. Dalam artian semakin tinggi efikasi diri seseorang, maka seseorang akan lebih bersemangat dalam menyelesaikan tugas yang ada, sebaliknya semakin rendah efikasi diri seseorang maka semakin menurun pula semangatnya dalam mengerjakan aktivitas tersebut. Hal ini menunjukkan bahwa efikasi diri adalah faktor internal yang mendominasi penyelesaian suatu aktivitas. Mahasiswa yang memiliki efikasi diri yang tinggi akan menyebabkan ia beranggapan bahwa kesulitan dalam mempelajari dan berkomunikasi dalam bahasa asing adalah sebuah tantangan. Keyakinan akan tantangan tersebut dapat mereduksi rasa cemas yang timbul saat komunikasi berlangsung. Kedua faktor tersebut di atas, baik secara masing-masing maupun secara bersamaan akan dapat mengurangi kecemasan mahasiswa dalam menghadapi kesulitan belajar, seperti ketika belajar bahasa. Dalam konteks pembelajaran, kolaborasi kedua faktor di atas juga dapat menurunkan kecemasan mahasiswa ketika berkomunikasi dalam bahasa asing.

Respati dan Pratomo (2008) meneliti tentang hubungan antara efikasi diri dengan foreign language anxiety pada mahasiswa Universitas Indonusa Esa Unggul menunjukkan bahwa hubungan antara kedua variabel tersebut memiliki kekuatan hubungan yang sedang. Kemudian, penelitian yang dilakukan oleh Djafri dan Wimbarwati (2011) dengan judul "Measuring Foreign Language Anxiety among Indonesian Undergraduate Students in Foreign Language Classrooms: In Relation with Students' Motivation and Their Perception toward Teachers' Behaviors" menyimpulkan bahwa motivasi hanya sedikit memberikan kontribusi di dalam mereduksi kecemasan, sementara persepsi mahasiswa terhadap perilaku dosen menjadi prediktor dalam kecemasan berbahasa asing.

\section{METODE PENELITIAN}

Penelitian ini adalah penelitian kuantitatif dengan menggunakan teknik analisis regresi linier berganda. Populasi penelitian adalah mahasiswa Jurusan Pendidikan Bahasa Inggris Institut Agama Islam Negeri Langsa. Sampel dipilih dengan menggunakan teknik Stratified Random Sampling yang diambil secara acak 
DOI : 10.32505/enlighten.v1i2.784

dan proporsional pada masing-masing semester (semester 2, 4, dan 6). Sampel yang terpilih kemudian diketahui berjumlah 147.

Instrumen penelitian yang dipakai sebagai alat ukur variabel terbagi atas dua bentuk, yaitu skala psikologi yang telah baku dan skala yang dikembangkan sendiri orlh peneliti dengan mempedomai indikator dari masing-masing variabel. Skalaskala tersebut diajukan kepada mahasiswa yang dirumuskan dalam bentuk pernyataan dengan empat alternatif jawaban yang sesuai dengan tujuan pernyataan. Instrumen pengukuran dalam penelitian ini adalah:

1. Foreign Language Classroom Anxiety Scale (FLCAS), yang dikembangkan oleh Horwitz, dkk. (1986), yang terdiri atas aspek: communication apprehension, test anxiety, dan fear of negative evaluation. Setelah diuji coba, keseluruhan aitem (33 aitem) dinyatakan valid dengan koefisien butirnya bergerak dari $r=0,440$ sampai $r=0,770$ dengan indeks reliabilitas Cronbach's Alpha $=0,950$.

2. Skala efikasi diri, yang disusun berdasarkan 3 aspek efikasi diri menurut Bandura (1997), yaitu: magnitude, strength, dan generality. Setelah diuji coba, 24 aitem dinyatakan valid dengan koefisien butirnya bergerak dari $r=0,386$ sampai $r=0,763$ dengan indeks reliabilitas Cronbach's Alpha $=0,858$.

3. Skala perilaku asertif, yang disusun berdasarkan indikator perilaku asertif yang dikemukakan oleh Townend (2007), yaitu: using "I-statement", making eyecontact, listening to others, engaging with others, open body posture and gesture, dan asking and giving positive feedback. Setelah diuji coba, 33 aitem dinyatakan valid dengan koefisien butirnya bergerak dari $r=0,404$ sampai $r=$ 0,757 dengan indeks reliabilitas Cronbach's Alpha $=0,926$.

\section{HASIL PENELITIAN}

Uji normalitas sebaran dianalisis dengan menggunakan formula Kolmogorov-Smirnov. Hasil menunjukkan bahwa data dari ketiga variabel yang dianalisis berdistribusi normal. Sebagai kriteria, apabila signifikansi > 0,05 maka data berdistribusi normal. Sebaliknya, apabila signifikansi $<0,05$ maka data tidak 
DOI : 10.32505/enlighten.v1i2.784

berdistribusi normal (Kadir, 2016). Tabel berikut ini merupakan rangkuman hasil perhitungan uji normalitas:

Tabel 1. Hasil Perhitungan Uji Normalitas

\begin{tabular}{cccccc}
\hline Var & $\bar{x}$ & SD & K-Z & Sig. & Ket \\
\hline FLA & 91,01 & 13,12 & 0,044 & 0,200 & $\mathrm{~N}$ \\
\hline EF & 57,07 & 8,22 & 0,065 & 0,200 & $\mathrm{~N}$ \\
\hline PAD & 75,44 & 11,21 & 0,062 & 0,200 & $\mathrm{~N}$ \\
\hline
\end{tabular}

Keterangan:

$$
\begin{array}{ll}
\text { Var } & =\text { Variabel } \\
\bar{x} & =\text { Mean } \\
\mathrm{SD} & =\text { Standar Deviasi } \\
\mathrm{Sig} . & =\text { signifikansi } \\
\mathrm{K}-\mathrm{Z} & =\text { Kolmogorov-Smirnov } \\
\mathrm{N} & =\text { Berdistribusi Normal }
\end{array}
$$

Tabel 2. Hasil Perhitungan Uji Linieritas

\begin{tabular}{cccl}
\hline & F & Sig. & Ket \\
\hline $\mathrm{X}_{1}-\mathrm{Y}$ & 1,055 & 0,404 & Linier \\
\hline $\mathrm{X}_{2}-\mathrm{Y}$ & 1,118 & 0,319 & Linier \\
\hline
\end{tabular}

Keterangan:

$$
\begin{array}{ll}
\mathrm{X}_{1} & =\text { Efikasi Diri } \\
\mathrm{X}_{2} & =\text { Perilaku Asertif Dosen } \\
\mathrm{Y} & =\text { Foreign Language Anxiety } \\
\mathrm{F} & =\text { Koefisien Deviation of Linearity } \\
\text { Sig. } & =\text { signifikansi }
\end{array}
$$

Uji linieritas hubungan dimaksudkan untuk mengetahui derajat hubungan variabel bebas dengan variabel terikat. Artinya, apakah efikasi diri dan perilaku asertif dosen dapat menerangkan timbulnya foreign language anxiety. Hasil analisis menunjukkan bahwa antara variabel bebas (efikasi diri dan perilaku asertif dosen) 
DOI : 10.32505/enlighten.v1i2.784

mempunyai hubungan yang linier terhadap variabel terikat (foreign language anxiety). Sebagai kriterianya, apabila sig. > 0,05 maka dinyatakan mempunyai hubungan yang linier (Priyatno, 2014).

Berdasarkan hasil analisis regresi berganda, diketahui bahwa terdapat kontribusi yang signifikan antara efikasi diri $\left(\mathrm{X}_{1}\right)$ dan perilaku asertif dosen $\left(\mathrm{X}_{2}\right)$ terhadap foreign language anxiety $(\mathrm{Y})$. Hal ini ditunjukkan dengan nilai koefisien Freg $=101,061$ dan sig. $=0,000$. Berikut adalah hasil analisi regresi berganda:

Tabel 3. Hasil Analisis Regresi Berganda

\begin{tabular}{cccccc}
\hline Model & $\mathbf{r}$ & $\mathbf{r}^{2}$ & Freg & Sig. & $\begin{array}{c}\text { SE } \\
(\boldsymbol{\%})\end{array}$ \\
\hline $\mathrm{X}_{12}-\mathrm{Y}$ & 0,764 & 0,584 & 101,061 & 0,000 & 58,4 \\
\hline
\end{tabular}

Keterangan:

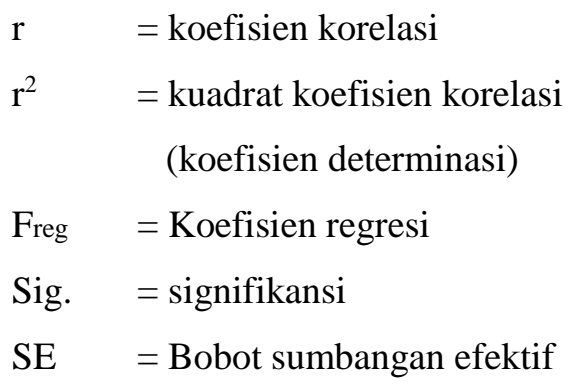

Tabel 4. Hasil Analisis Hubungan Parsial

\begin{tabular}{cccccc}
\hline Model & $\mathbf{r}$ & $\mathbf{r}^{2}$ & $\mathbf{t}$ & Sig. & $\begin{array}{c}\text { SE } \\
(\%)\end{array}$ \\
\hline $\mathrm{X}_{1}-\mathrm{Y}$ & 0,703 & 0,494 & $-6,395$ & 0,000 & 49,4 \\
\hline $\mathrm{X}_{2}-\mathrm{Y}$ & 0,683 & 0,466 & $-5,584$ & 0.000 & 46,6 \\
\hline
\end{tabular}

Dari rangkumantabel di atas diketahui koefisien korelasi antara $\mathrm{X}_{1}$ dan $\mathrm{Y}$ sebesar 0,703 dengan bobot sumbangan efektif sebesar 49,4\% dengan $\mathrm{t}$ bernilai negatif (sig < 0,05). Hal ini menunjukkan bahwa efikasi diri memiliki hubungan yang negatif secara signifikan dan memberikan sumbangan sebesar 49,4\% terhadap foreign language anxiety. Artinya, semakin tinggi efikasi diri yang dimiliki, maka akan foreign language anxiety akan semakin rendah, begitu pula sebaliknya. 
DOI : $10.32505 /$ enlighten.v1i2.784

Kemudian diketahui koefisien korelasi antara $\mathrm{X}_{2}$ dan $\mathrm{Y}$ sebesar 0,683 dengan bobot sumbangan efektif sebesar 46,6\% dengan t bernilai negatif ( $\operatorname{sig}<0,05$ ). Hal ini menunjukkan bahwa perilaku asertif dosen memiliki hubungan yang negatif secara signifikan dan memberikan sumbangan sebesar 46,6\% terhadap foreign language anxiety. Artinya, semakin tinggi perilaku asertif yang dimiliki oleh dosen, maka akan foreign language anxiety akan alami mahasisw akan semakin rendah, begitu pula sebaliknya.

Tabel 4. Hasil Perhitungan Mean Hipotetik dan Mean Empirik

\begin{tabular}{|c|c|c|c|}
\hline \multirow{2}{*}{ Variabel } & \multicolumn{2}{|c|}{ Mean } & \multirow{2}{*}{ Keterangan } \\
\hline & Hipotetik & Empirik & \\
\hline Foreign & \multirow{3}{*}{82,5} & \multirow{3}{*}{91,01} & tergolong \\
\hline Language & & & tinggi \\
\hline Anxiety & & & \\
\hline \multirow[t]{2}{*}{ Efikasi Diri } & \multirow[b]{2}{*}{60} & \multirow[b]{2}{*}{57,07} & tergolong \\
\hline & & & menengah \\
\hline Perilaku & \multirow{3}{*}{82,5} & \multirow{3}{*}{75,44} & \multirow{3}{*}{$\begin{array}{l}\text { tergolong } \\
\text { menengah }\end{array}$} \\
\hline Asertif & & & \\
\hline Dosen & & & \\
\hline
\end{tabular}

Berdasarkan perbandingan kedua nilai mean di atas (mean hipotetik dan mean empirik), maka dapat dinyatakan bahwa subjek penelitian memiliki kecemasan berbahasa asing yang tinggi, efikasi diri pada level menengah, dan perilaku asertif yang dimiliki dosen tergolong menengah.

\section{DISKUSI}

Kecemasan merupakan atribut psikologis yang sangat sulit dijelaskan, meskipun sangat mudah dipahami karena pernah dialami oleh semua orang. Kesulitan dalam menjelaskan kecemasan ini disebabkan oleh banyaknya faktor yang dapat memicu timbulnya kecemasan tersebut. Seperti halnya kecemasan pada umumnya, foreign language anxiety yang dialami oleh pembelajar bahasa asing 
DOI : 10.32505/enlighten.v1i2.784

(foreign language learner) juga ditentukan oleh banyak faktor. Faktor-faktor yang banyak tersebut oleh Tóth (2010) dikelompokkan ke dalam 7 jenis yaitu, kealamian ketika berkomunikasi dengan bahasa asing, kepribadian dan karakter, tuntutan studi, kompetensi bahasa, tujuan pembelajaran, keterbatasan akses berkomunikasi, serta situasi ruang kelas, pengajar, dan lawan bicara. Faktor kepribadian dan karakter merupakan salah satu faktor internal yang sangat berpengaruh dalam memicu kecemasan yang muncul dalam diri individu.

Salah satu faktor psikologi yang mampu menguraikan permasalahan yang berkaitan dengan kecemasan adalah efikasi diri. Efikasi diri yang dimiliki akan meningkatkan rasa kepercayaan diri mahasiswa saat mengikuti perkuliahan. Efikasi diri pula merefleksikan diri untuk mampu menghadapi kesulitan yang dihadapi dalam perkuliahan. Seseorang yang memiliki efikasi diri yang tinggi akan mampu menyelesaikan permasalahannya studinya dengan baik. Efikasi diri yang tinggi akan membentuk kepribadian yang penuh dengan keyakinan. Keyakinan diri yang tinggi akan membuat individu mampu menghadapi masalah dengan cara yang tenang. Mahasiswa dengan tingkat keyakinan yang tinggi akan mampu menemukan strategi untuk menghadapi dan memecahkan tantangan yang ia hadapi di bangku perkuliahan. Efikasi diri yang tinggi baik secara langsung maupun tidak langsung akan menurunkan tingkat kecemasan yang dialami mahasiswa, termasuk kecemasan berbahasa asing (foreign language anxiety). Hal tersebut akan dapat mereduksi rasa cemas yang muncul baik yang diketahui atau tidak diketahui sebabnya. Di samping itu, seseorang yang panik akibat dari munculnya rasa cemas yang sangat tinggi akan membuat ia tidak mampu berpikir dengan baik, meskipun sebelumnya telah dipersiapkan dengan baik.

Dari eksposisi di atas, dapat dimaknai bahwa untuk menghilangkan kecemasan yang dialami ketika mempelajari Bahasa Inggris diperlukan keyakinan diri. Mahasiswa yang yakin akan kemampuan dirinya akan dapat berpikir efektif yang akan menuntunnya dalam mengerjakan tugas-tugas perkuliahan dan menampilkan kemampuan berkomunikasi berbahasa Inggris dengan baik.

Hasil penelitian ini membuktikan adanya hubungan yang signifikan antara efikasi diri dengan foreign language anxiety yang ditunjukkan dengan nilai koefisien korelasi parsial sebesar -0,703. Hal ini menunjukkan bahwa adanya 
DOI : 10.32505/enlighten.v1i2.784

hubungan negatif antara variabel bebas dengan variabel terikat. Artinya, semakin tinggi efikasi diri mahasiswa, maka akan semakin rendah foreign language anxiety yang dialami mahasiswa dalam berkomunikasi dan mempelajari Bahasa Inggris pada perkuliahan. Sebaliknya, semakin rendah efikasi diri yang dimiliki mahasiswa, maka akan semakin tinggi kecemasan berbahasa asing yang akan dialami.

Berdasarkan hasil temuan ini, maka hipotesis yang menunjukkan adanya hubungan negatif antara efikasi diri dengan foreign language anxiety yang diajukan dalam penelitian ini dapat diterima. Hal ini sesuai dengan pendapat Bandura (1997) bahwa individu yang memiliki efikasi diri yang tinggi memiliki keyakinan yang tinggi terdorong untuk penuh inisiatif untuk menyelesaikan tugas-tugas belajar dalam keadaan apapun. Keyakinan diri yang kuat akan membuat seseorang menganggap bahwa kesulitan adalah sebuah tantangan yang harus di selesaikan.

Faktor yang muncul dari pihak pengajar merupakan hal yang tidak dapat dinafikan. Sebagai salah satu faktor eksternal, perilaku seorang pengajar akan menentukan suasana pembelajaran, yang pada akhirnya akan menentukan kondisi psikologis para peserta didiknya. Hal ini juga senada dengan penelitian yang dilakukan oleh Djafri dan Wimbarwati (2011) yang menjelaskan bahwa perilaku seorang pengajar dalam berinteraksi dengan peserta didiknya menjadi salah satu sumber dari foreign language anxiety.

Dalam konteks pembelajaran di perkuliahan, dosen bukan saja bertindak sebagai pengajar, melainkan juga sebagai partner atau lawan berbicara. Komunikator yang berkomunikasi dengan seseorang yang ia anggap memiliki tingkat kemampuan yang lebih tinggi akan membuatnya merasa cemas. Artinya, secara alami seseorang mahasiswa telah mengalami kecemasan saat berbicara dengan dosennya dalam bahasa asing. Ketika mahasiswa melakukan kesalahan dalam mengartikulasikan pikiran maupun perasaannya, baik kesalahan dalam hal pengucapan (pronunciation), salah ucap (slip tongue), dan sebagainya, dosen yang baik akan memberikan respon dan koreksi yang tepat yang tidak menyakitkan perasaan atau membuat mahasiswanya merasa malu. Disini peran asertivitas muncul untuk mereduksi kecemasan yang mereka alami. 
DOI : $10.32505 /$ enlighten.v1i2.784

Hasil penelitian ini menguatkan bahwa adanya hubungan negatif yang signifikan antara perilaku asertif dosen dengan foreign language anxiety yang ditunjukkan dengan nilai koefisien korelasi parsial sebesar -0,683. Artinya, semakin tinggi perilaku asertif yang ditunjukkan oleh dosen, maka akan semakin rendah foreign language anxiety yang dialami mahasiswa dalam berkomunikasi dan mempelajari Bahasa Inggris pada perkuliahan. Sebaliknya, semakin rendah asertivitas yang ditunjukkan dalam perilaku dosen, maka akan semakin tinggi kecemasan berbahasa asing yang akan dialami.

Koefisien determinasi dari interaksi antara variabel efikasi diri dan perilaku asertif dosen dengan variabel foreign language anxiety adalah sebesar $r^{2}=0,584$ atau 58,4\%, sementara 41,6\% dipengaruhi dan dibentuk oleh variabel lain di luar prediktor yang digunakan dalam penelitian ini. Temuan ini menunjukkan bahwa efikasi diri dan perilaku asertif dosen memiliki pengaruh yang besar (lebih dari $50 \%$ ) foreign language anxiety yang dialami mahasiswa, mengingat ada banyak faktor lain yang dapat memicu timbulnya kecemasan.

\section{KESIMPULAN}

Penelitian ini menemukan bahwa ada hubungan negatif yang signifikan antara efikasi diri dan perilaku asertif dosen dengan foreign language anxiety. Kecemasan pada hakikatnya merupaksn sesuatu yang sangat lumrah terjadi dalam diri manusia. Namun demikian, kecemasan yang timbul harus direduksi semaksimal mungkin karena foreign language anxiety akan sangat mengganggu proses akuisisi bahasa asing. Salah satu faktor internal yang dapat menurunkan rasa cemas yang timbul adalah keyakinan dari diri mahasiswa itu sendiri. Dengan efikasi diri yang tinggi, seseorang akan menganggap suatu kesulitan adalah sebuah tantangan yang harus dihadapi. Dengan demikian, maka mahasiswa perlu melatih diri untuk meningkatkan efikasi dirinya.

Perilaku dosen ketika berinteraksi dan berkomunikasi juga berpengaruh terhadap timbulnya kecemasan berbahasa asing pada diri mahasiswa. Perilaku dosen yang agresif akan membuat mahasiswa tidak nyaman ketika berkomunikasi. Hal tersebut memicu meningkatnya rasa cemas yang dialami mahasiswa. Sebaliknya, perilaku dosen yang asertif akan mendorong rasa percaya diri 
mahasiswa untuk mengungkapkan pengetahuan, ide, pikiran, dan perasaannya melalui kemampuan berbahasa asing. Dengan demikian, dosen juga bertanggung jawab untuk meningkatkan asertivitasnya dalam rangka menciptakan lingkungan yang kondusif untuk mempelajari bahasa asing.

\section{DAFTAR RUJUKAN}

Bandura, A. (1997). Self Efficacy: The Exercise of Control. New York, NY: W.H. Freeman and Company.

Crystal, D. (2003). English as a Global Language (2nd ed.). Cambridge: Cambridge University Press.

Djafri, F. \& Wimbarti S. (2015). Measuring Foreign Language Anxiety among Indonesian Undergraduate Students in Foreign Language Classrooms: In Relation with Students' Motivation and Their Perception toward Teachers' Behavior. Yogyakarta: Universitas Gadjah Mada.

Dulay, H., Burt, M., \& Krashen, S. D. (1982). Language Two. New York, NY: Oxford University Press.

Heider, F. (1958). The Psychology of Interpersonal Relations. New York, NY: Wiley.

Horwitz, E. K. (2001). Language Anxiety and Achievement. Annual Review of Applied Linguistics 21, 112-126.

Horwitz, E. K. (2016). Factor Structure of the Foreign Language Classroom Anxiety Scale: Comment on Park (2014). Psychological Reports 0 (0), 1-6. doi: $10.1177 / 0033294116653368$

Horwitz, E. K., Horwitz, M. B., \& Cope, J. (1986). Foreign Language Classroom Anxiety. The Modern Language Journal 86 (4), 562-570.

Humphries, R. (2011). Language Anxiety in International Students: How Can It be Overcome? Griffith Working Papers in Pragmatics and Intercultural Communication 4, (1/2), 65-77.

Kadir. (2016). Statistika Terapan: Konsep, Contoh, dan Analisis Data dengan Program SPSS/Lisrel dalam Penelitian. Jakarta: RajaGrafindo Persada.

Krashen, S. D. (1982). Principles and Practice in Second Language Acquisition. Oxford: Pergamon.

Luo, H. (2014). Foreign Language Speaking Anxiety: A Study of Chinese Language Learners. Journal of the National Council of Less Commonly Taught Languages 15, 99-117. 
Priyatno, D. (2014). SPSS 22: Pengolahan Data Terpraktis. Yogyakarta: Penerbit Andi.

Rakhmat, J. (2005). Psikologi Komunikasi. Bandung: Remaja Rosdakarya.

Respati, W. S. \& Prastomo, O. T. (2008). Hubungan antara Self-Efficacy dengan Foreign Language Anxiety pada Mahasiswa Universitas Indonusa Esa Unggul. Jurnal Psikologi 6 (2), 70-74.

Tóth, Z. (2010). Foreign Language Anxiety and the Advanced Language Learner: A Study of Hungarian Students of English as a Foreign Language. Newcastle upon Tyne: Cambridge Scholars Publishing.

Townend, A. (2007). Assertiveness and Diversity. New York, NY: Palgrave Macmillan.

Yoenanto, N. H. \& Rahadianto, A. I. (2014). Hubungan Antara Self-Efficacy dan Motivasi Berprestasi dengan Kecemasan Akademik pada Siswa Program Sekolah RSBI di Surabaya. Jurnal Psikologi Industri dan Organisasi 3 (3), 123-128.

Zimmerman, B. J. (2009). Self-Efficacy and Educational Development. dalam A. Bandura (Ed.), Self Efficacy in Changing Societies, (hal. 202-231). Cambridge: Cambridge University Press. 